\title{
Тувинское сказание «Богда Чангар хан» и его константные сегменты в ойратской и калмыцкой версиях героического эпоса «Джангар»"
}
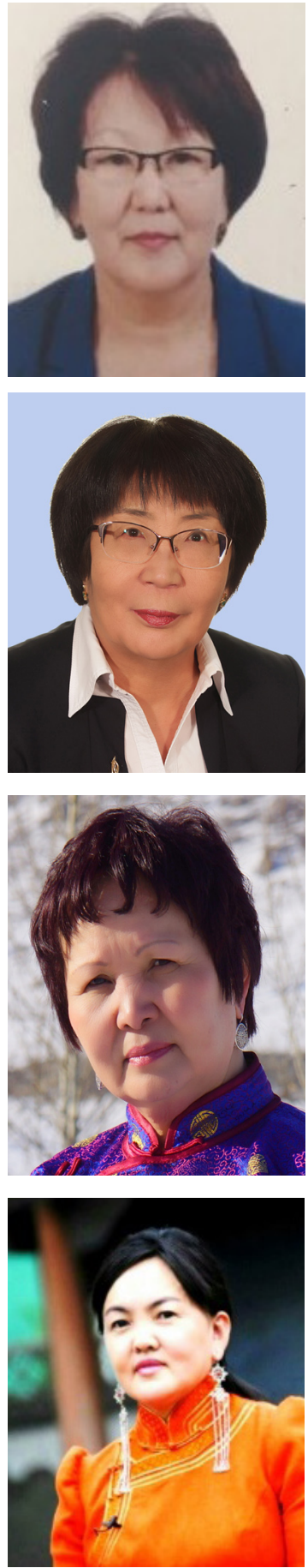

Евдокия Э. Хабунова

Калмыцкий государственный университет им. Б. Б. Городовикова, Российская Федерация, Людмила С. Дампилова

Институт монголоведения, буддологии и тибетологии СО РАН, Российская Федерация,

Маргарита Б.-О. Кунгаa

Тувинский институт гуманитарных и прикладных социально-экономических исследований при Правительстве Республики Тыва, Российская Федерации,

\section{Алимаа Аюушжавийин}

Институт языка и литературы Академии наук Монголии, Монголия

В статье анализируются уровни и степени сходства тувинского сказания «Богда Чангар хаан» (Богда Чангар хан), записанного у сказителя Баяна Балбыра Узуновича (1881-1962), с ойратской и калмыцкой версиями героического эпоса «Джангар». Текст тувинского сказания хранится в фонде Тувинского института гуманитарных и прикладных социально-экономических исследований, текст калмыцкого эпоса рассматривается в версии издания «"Джангар". Калмыцкий героический эпос» (1978).

Рассматриваются сюжетные слагаемые, которые отличаются константностью в эпическом нарративе. Исследование базируется на теории этнопоэтических констант В. М. Гацака и др. научных методах. Особое внимание уделяется мотивам и формулам, типичным для эпоса монгольских народов как в структурно-семантическом плане, так и в своем вербальном воплощении. Этнопоэтические константы рассматриваются разных уровней: сюжет о богатырских действиях; мотивы: весть о противнике, выбор богатыря, отправление в дорогу, расправа с противником и т. д.

Отмечается, что тувинское сказание является результатом творчества сказителя, знакомого с ойратской эпической традицией и сумевщего адаптировать «принесенный» сюжет в тувинскую фольклорную среду, сохранив важные для эпического повествования константные сегменты, указывающие на типологическое сходство эпической традиции тюрко-монгольских народов.

Ключевые слова: эпос; тувинцы; ойраты; калмыки; этнопоэтические константы; Джангар; Богда Чангар хан; тувинский фольклор; калмыцкий фольклор

"Исследование выполнено при финансовой поддержке РФФИ в рамках научного проекта «Аннотированный каталог традиционных мотивов эпоса монгольских народов» (№ 18-512-94006).

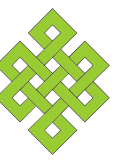

Для цитирования:

Хабунова Е. Э., Дампилова Л. С., Кунгаа М. Б., Аюушжавийин А. Тувинское сказание «Богда Чангар хан» и его константные сегменты в ойратской и калмыцкой версиях героического эпоса «Джангар» [Электронный ресурс] // Новые исследования Тувы. 2019, № 4. URL: https:// nit.tuva.asia/nit/article/view/887 (дата обращения: дд.мм.гг.). DOI: 10.25178/nit.2019.4.9

Хабунова Евдокия Эрендженовна - доктор филологических наук, профессор, директор международного научного центра «Культурное наследие монгольских народов» Калмыцкого государственного университета им. учного центра «Культурное наследие монгольских народов» Калмыцкого государственного университета им. khabunova@mail.ru ORCID ID: 0000-0002-2113-6877

Дампилова Людмила Санжибоевна - доктор филологических наук, главный научный сотрудник отдела литературоведения и фольклористики Института монголоведения, буддологии и тибетологии Сибирского отделения Российской академии наук. Адрес: Россия, 670047, г. Улан-Удэ, ул. Сахьяновой, д. 6. Тел.: +7 (983) 435-30-28. Эл. адрес: dampilova luda@ rambler.ru ORCID ID: 0000-0003-0917-5432

Кунгаа Маргарита Базыр-ооловна - кандидат педагогических наук, ведущий научный сотрудник сектора фольклора Тувинского института гуманитарных и прикладных социально-экономических исследований. Адрес: 667000, Россия, г. Кызыл, ул. Кочетова, д. 4 . Тел.: +7 (394-22) 2-39-36. Эл. адрес: m.b.kungaa@mail.ru

Аюушжавийин Алимаа - доктор наук (PhD), заведующая отделом фольклора Института языка и литературы Академии наук Монголии. Адрес: Монголия, г. Улан-Батор, ул. Жукова, д. 68. Тел.: +7 (976) 98111378. Эл. адрес: alimaa_mgl@yahoo. com ORCID: 0000-0002-3533-2000

Khabunova Evdokia Erendzhenovna, Doctor of Philology, Professor, Director of International Scientific Centre 'Cultural Heritage of Mongolic Peoples', Gorodovikov Kalmyk State University. Postal address: 11, Pushkin St., 358000 Elista, Russia. Tel.: +7 (909) 396-90-54. E-mail: khabunova@mail.ru

Dampilova Ludmila Sandzhiboevna, Doctor of Philology, Chief Research Associate, Department of Literature and Folklore Research, Institute for Mongolian, Buddhist and Tibetan Studies, Siberian Branch of the Russian Academy of Sciences. Postal address: 6, Sakhyanova St., Ulan-Ude, 670047, Russia. Tel.: +7 (983) 43530-28.E-mail: dampilova_luda@rambler.ru

Kungaa Margarita Bazyr-oolovna, Candidate of Pedagogy, Leading Research Associate, Department of Folklore, Tuvan Institute for Humanities and Applied SocioEconomic Research. Postal address: 4, Kochetov St., 667000, Kyzyl, Russian Federation. Tel.: +7 (394-22) 2-39-36. E-mail: m.b.kungaa@mail.ru

Ayuushzhaviyin Alimaa, $\mathrm{PhD}$ (Cultural Study), Head of Folklore Department, Institute of Language and Literature, Mongolian Academy of Sciences. Postal address: 68, Zhukov St., Ulaanbaatar, Mongolia. Tel.: +7 (976) 98111378. E-mail: alimaa_mgl@yahoo.com 


\title{
The Tuvan legend 'Bogda Changar Khan' and its constant segments in the Oirat and Kalmyk versions of the heroic epic of "Jangar"
}

\author{
Evdokia E. Khabunova \\ Gorodovikov Kalmyk State University, Russian Federation, \\ Ludmila S. Dampilova \\ Institute for Mongolian, Buddhist and Tibetan Studies, Siberian Branch of the Russian Academy of Sciences, \\ Russian Federation, \\ Margarita B. Kungaa \\ Tuvan Institute for Humanities and Applied Socio-Economic Research, Russian Federation, \\ Alimaa Ayuushzhaviyin \\ Institute of Language and Literature, Mongolian Academy of Sciences, Mongolia
}

The article analyzes levels and grades of affinity between the Tuvan legend 'Bogda Changar-khaan", recorded from the taleteller Bayan U. Balbyr (1881-1962), and the Oirat and Kalmyk version of the heroic epic of 'Jangar'. The text of the Tuvan legend is stored in the Tuvan Institute for Humanities and Applied Socio-Economic Research, the considered text of the Kalmyk epic is that of the 1978 edition - 'Jangar. The Kalmyk Heroic Epic'.

The paper examines plot components characterized by varied constancy within the epic narrative. The study is based on the theory of ethno-poetic constants by V. M. Gatsak and other scientific methods. Special attention is paid to motifs and formulas typical for epics of Mongolic peoples both structurally, semantically, and verbally. The study deals with ethno-poetic constants of various levels: the plot about heroic actions; motifs: the message about the enemy's arrival, selection of a hero, departure of the latter, punishment of the aggressor, etc.

It is noted that the Tuvan legend emerged as a result of the taleteller's creative work who had been familiar with the Oirat epic tradition and was able to adapt the 'imported' plot within the Tuvan folklore environment, retaining some important epic constant segments that indicate the typological affinity of the epic tradition of Turko-Mongols.

Keywords: epic; Tuvans; Oirats; Kalmyks; ethno-poetic constants; Jangar; Bogda Changar Khan; Tuvan folklore; Kalmyk folklore

"The reported study was funded by RFBR according to the research project 'The Annotated Catalogue of Traditional Motifs of the Epos of the Mongolian Peoples' (№18-512-94006).

\section{For citation:}

Khabunova E. E., Dampilova L. S., Kungaa M. B. and Ayuushzhaviyin A. The Tuvan legend 'Bogda Changar Khan' and its constant segments in the Oirat and Kalmyk versions of the heroic epic of 'Jangar'. The New Research of Tuva. 2019, no. 4. URL: https://nit.tuva.asia/nit/article/view/887 (access date ... ). DOI: 10.25178/nit.2019.4.9

\section{Введение}

Эпическая традиция «Джангара» широко бытовала среди калмыков и ойратов Западной Монголии и Синьцзян-Уйгурского автономного района Китая; была известна другим монгольским (халха-монголам, бурятам, иссык-кульским сарт-калмакам) и тюркским (тувинцам и алтайцам) народам.

Героика эпических сказаний и стереотипы поэтического мироощущения народа, основанные на их жизненных ценностях и формирующие типологическое сходство национальных эпосов, не теряют своей актуальности, несмотря на различие языка, форм и способов художественной вербализации эпических сюжетов и мотивов.

Ареал распространения и характер взаимодействия данной эпической традиции, масштабы взаимопроникновения и контаминаций разных сюжетов и мотивов, степень их сохранности в разноязычном текстовом воплощении - эти вопросы представляются актуальными для изучения природы однородных явлений, обнаруживаемых в произведениях устного народного творчества тюрко-монгольских народов, в частности, в эпических нарративах.

Проблема типологии эпоса тюрко-монгольских народов исследована в части выявления в них архаического сюжета о героической женитьбе богатыря и его борьбе с иноземными противниками, реализованного через ряд сходных мотивов (чудесное рождение, наречение имени, добыча невесты, брачные состязания и т. д.). Эти особенности тюрко-монгольского эпоса отмечены российскими и 
зарубежными учеными (Гребнев, 1960; Мелетинский, 1963; Жирмунский, 1974; Короглы, 1975; Пухов, 1975; Суразаков, 1985; Путилов, 1997; Куулар, 1973; 2004; Кичиков, 1973; Reichl, 1992; Орус-оол, 2001; Кунгаa, 2019; Убушиева, Дамринжав, 2019 и др.). Вместе с тем способы и характер вербализации мотивов, проявляющихся по-разному в национальных эпосах, все еще требуют детального анализа.

В статье особое внимание уделяется изучению текстового воплощения эпических мотивов и формул в тувинском сказании «Богда Чангар хан», рассматривается семантика константных сегментов, передающих поэтико-стилевые особенности эпического нарратива. Выявляется, что лежит в основе однородных явлений и что отражает национальную специфику тувинского эпического сказания «Богда Чангар хан», записанного у тувинского сказителя Баяна Балбыра в приграничном с Западной Монголией регионе.

Механизм создания единого эпоса, сохранившегося в различных версиях (национальных, локальных), природа внутренних сцеплений, глубинных связей этой эпической целостности и ее отдельных повествовательных конструкций и деталей, отличающихся постоянством во всех версиях, становятся понятными в процессе выявления эмпирических данных из самого текста. Представляется продуктивным «копнуть вглубь» фактуры однородных явлений тувинского сказания «Богда Чангар хан» и эпоса «Джангар»).

Эпическая общность тюрко-монгольских народов формировалась в условиях их тесных контактов, взаимовлияния их языков и культур, на фоне сходного уклада кочевой жизни и единой цивилизационной среды. Мобильность номадов, их неподдельный интерес к новому, способность извлекать полезное из опыта других народов значительно расширяли мировоззренческое и креативное пространство творцов словесного искусства. В числе таких одаренных людей был и тувинец Баян Балбыр Узунович (1881-1962), проживавший в местности Эн-Суг, усвоивший у сказителя Донгур-Хемчик (букв.: человек из долины Хемчик, не носивший косичку) сказание «Богда Чаңгар хаан» (Богда Чангар хан). По предположению тувинского исследователя Д. С. Куулара, данное произведение «... на восток принес человек с запада, из района, граничащего с Алтаем» (Куулар, 2004: 143-148).

Сказание «Богда Чаңгар хаан» (Богда Чангар хан), записанный Д. С. Кууларом в сентябре 1957 г. в местности Эн-Суг хранится в Рукописном фонде Тувинского института гуманитарных и прикладных социально-экономических исследований среди материалов личного архива ученого в виде машинописного текста на тувинском языке, объемом 5 стр. В 1969 г. данное произведение было переведено на русский язык Д. С. Кууларом и опубликовано в издании «Ученые записки» КНИИЯЛИ (на данный момент Калмыцкий научный центр РАН) (Куулар, 1973: 122-129). Русскоязычный текст послужил источником для перевода тувинского сказания «Богда Чангар хан» на монгольский язык С. Бадраа и публикации в журнале «Аман зохиол судлал» (Аман зохиол судлал, 1978: 200-204).

Сюжет тувинского сказания «Богда Чангар хан» начинается, как и в главах ойратской и калмыцкой версиях эпоса «Джангар», с констатации эпических событий (Кичиков, 1973: 120). Эта особенность объясняется наличием в эпосе пролога, предшествующего эпическим главам и характеризующего эпическую среду, место и время, на фоне которой разворачиваются основные богатырские действия. Сказители не всегда повторяют его, если одна глава исполняется за другой. Отсутствие описания эпической статики в тувинском сказании «Богда Чангар хан» позволяет предположить, что оно являлось частью многосоставного эпического нарратива. Известно, что в Туве встречаются и другие произведения, которые восходят к эпосу «Джангар» (Кунгаа, 2019: 79).

В сюжете тувинского сказания исследователями (Загдсурэн, 1978; Кичиков 1973; Куулар, 2004; Кунгаа 2019) уже отмечалось «наличие целого ряда мотивов, общих для тувинского сказания «Богда Чангар хан» и эпоса «Джангар» ойратов и калмыков. Текстовое воплощение типических мест, названных B. М. Гацаком «этнопоэтическими константами», как правило, базируется на совокупности устойчивых выражений, скрепленных «опорным» словом (Гацак, 2000ab; 2002). Эти константные сегменты играют важную роль в конструировании эпического повествования и могут быть представлены в эпосе в виде формульных словосочетаний (односложных или развернутых) или «группы слов, встречающихся в одних и тех же метрических условиях, для выражения того или иного смысла» (Лорд, 1994: 42). Обратив особое внимание на константную организацию эпического текста, В. М. Гацак обнаружил, что «этнопоэтические константы» могут проступать на разных уровнях, им присущи формульность, но чаще константы обнаруживают подвижность очертаний (Гацак, 2000b: 94-103).

Константы, отображающие события жизненного цикла эпического героя эпоса монгольских народов, были исследованы Е. Э. Хабуновой (Хабунова, 2006: 13-121). 
Источниковой базой данного исследования послужили основные национальные версии героического эпоса «Джангар: калмыцкая, монголо-ойратская и синьцзян-ойратская. Тувинское сказание «Богда Чангар хан», рукопись которого хранится в Рукописном фонде Тувинского института гуманитарных и прикладных социально-экономических исследований, в контексте изучения константных единиц в его вербальном воплощении рассматривается впервые, в чем и заключается новизна данного исследования.

\section{Типизированные явления}

Оригинальный текст сказания «Богда Чаңгар хаан» (Богда Чангар хан) и текст его подстрочного перевода на русский язык с примечаниями и разбивкой на предложения были подготовлены одним из соавторов статьи М. Б. Кунгаа ${ }^{1}$.

Обратимся к тексту сказания «Богда Чаңгар хаан» (Богда Чангар хан) и определим в нем константные сегменты, указывающие на сходство с калмыцким и монголо-ойратским эпическим нарративом. В сравниваемых текстах константные единицы выделяются жирным шрифтом:

Весть о противнике.

Богда Чаңгар хаан тура чугаалап-тыр:

- Соңгу чүкте Каңмы-Какпа деп кижи-биле чаалажыр шаг келди эвеспе - дээш, улуг кожуун чыып, улуг кеңгиргезин дегзип, биче кожуунун чыып, биче кеңгиргезин дегзип туруп, «чаа болчаа келген» деп турган.

[Однажды] Богда Чангар каган говорит:

- С северной стороны [живущим] Канмы-Какпа воевать время пришло - сказав, [свой] большой кожуун собирая, в большой барабан трубя, [свой] малый кожуун собирая, в малый барабан трубя, «войны время пришло» говорил².

В данном фрагменте константность проявляется в том, что весть о существовании хана-антагониста сообщается державным ханом Богда Чангаром, собравшим своих поданных боем больших и малых барабанов.

Формула с аналогичной семантикой «оповещение и созыв народа» и скрепленная опорным словом «барабан», характерна и для эпической традиции монгольских народов:

Богд ноён Жангар хаан гэж/ Нэгэн хаан байв гэнээ/ Их хэнгэргээ цохиж / Их отгоо цуглуулаад / Бага хэнгэргээ цохиж/ Бага отгоо иуглуулаад (Аман зохиол судлал, 1978: 132). Богдо ноён Жангар называемый / Был один хан говорят / Били в большой барабан / Созывая [подданных] большой отуг (волость) / Били в малый барабан / Созывая [подданных] малый отуг³.

\section{Выбор богатыря.}

Постоянством в эпическом сюжете отличается мотив выбора богатыря для отправления в страну хана-антагониста. Тувинское сказание «Богда Чангар хан» не является исключением в плане реализации данного мотива в традиционном стиле: избранным для опасного задания героем оказывается единственный сын хана:

- Ол черже чоруур шериг-даа чок, ол оран чоруур эрлик кижи-даа чок, ол оранга чедир тозан чылдык чер болгай» - дижип турлар. Богда-Чаңгар хаан Чиргилчинниг-Шил-оол деп оолдуг чүвең иргин.

-Тозан чылдык черже менден башка чоруур кижи-даа чок-тур, Улуг-Кара-Маадырың бээр сен бе? деп адазындан айтырган.

- В ту сторону [могущего] поехать ни армии нет, в ту страну [могущего] поехать лихого богатыря нет, до той страны [надо ехать] девяносто лет - такая вот сторона - говорили. Богда-Чаңгар каган имел сына [по имени] Чиргилчинниг-Шил-оол Чиргилчинниг (букв.: с маревом; Шил-оол стеклянный мальчик) $)^{4}$.

\footnotetext{
${ }^{1}$ Рукопись М. Б. Кунгаа из 21 стр. компьютерного набора, содержащая разбивку на строки (1-78) оригинального и переводного текстов сказания «Богда Чаңгар хаан» (Богда Чангар хан).

${ }^{2}$ Стр. 1 рукописи М. Б. Кунгаа.

${ }^{3}$ Здесь и далее перевод монголоязычных текстов выполнен Е. Э. Хабуновой.

${ }^{4}$ Стр. 3 рукописи М. Б. Кунгаа.
} 
Здесь уместно провести параллель между Чиргилчинниг-Шил-оолом и сыном Джангара богдо Хошун Уланом (Улан Шовшур), наделяемым в синьцзян-ойратской и калмыцкой версиях эпоса «Джангар» эпитетом «улан» (красный). Многосоставность антропонимов в рассматриваемых случаях передает одну из особенностей эпической стилистики, направленной на мифологизацию и героизацию образа богатырей. В рассматриваемом случае составные части собственных имен передают особенности облика богатырей «чиргилчинниг» (с маревом) и «улан» (красный), излучающего свет, указывают на их чудесное рождение, избранность и другие индивидуальные особенности: отвага, неукротимость, горячность. Эпитетом «улан» (красный, алый) также наделяется отважный богатырь, именуемый в калмыцкой версии эпоса «Джангар» Арг Улан Хоңһр (Благородный Алый Хонгор), в монголоойратской - Уурьдын Улаан Хонгор (Ранний Алый Хонгор).

Отдаленность и опасность враждебного локуса предполагает поиск богатыря, способного преодолеть все препятствия и испытания и выполнить поручение державного хана. Отсутствие таковых в момент угрозы войны в стране Богда Чангар хана побуждает его сына -Чиргилчинниг-Шил-оола изъявить о своей решимости к борьбе с врагом, тем самым засвидетельствовать свое богатырское назначение:

- Тозан чылдык черже менден башка чоруур кижи-даа чок-тур, Улуг-Кара-Маадырың бээр сен бе? - деп адазындан айтырган.

- В девяносто лет преодолеваемое место кроме меня могущего поехать человека нет, своего Улуг-Кара-Маадыра (улуг - букв.: большой; кара - чёрный; маадыр - богатырь) дашь? - у отца спросил ${ }^{1}$.

- Чоруурун чоруур-ла мен, назын кыраан, ол черге четкеш, дедир ээп кээп, чуртумга сөөк салырым билдинмес боор - деп-тир.

- Поехать так-то могу поехать, [только] возраст старый, до той стороны доехав, обратно вернусь ли, в своей стране кости сложу ли, неизвестно - сказал ${ }^{2}$.

В просьбе Чиргилчинниг-Шил-оол разрешить взять Улуг-Кара-Маадыра, богатыря хана-отца, угадывается мотив физической незрелости и младенческого возраста героя, который еще не обрел своего коня.

Слова о труднодоступности места с семантикой «доберусь ли, вернусь ли?» в рассматриваемом сказании приписываются богатырю-соратнику Улуг-Кара-Маадыру. В ойратской и калмыцкой эпической традиции сомнения относительно непреодолимого расстояния «күрнүй, угай?» (доберется или нет?) как правило, высказывает ясновидец Алтан Чееджи, в отдельных случаях - богатырский конь.

Богатырские качества героя отображены в формуле, стандартной для эпоса тюрко-монгольских народов:

Тозан шар кежи көгээрде хойтпакты тос-таңма паш ышкаш хува-биле Аржы ламаның кадайы көөрде, бир куткаш, ийи-үш пакты ижип, көрбесте, чаңгыс хуваны чаңгыс пактап ижип олуруп-тур.

[Чиргилчинниг-Шил-оол] из девяносто волов шкуры [сделанного] көгээра хойтпак большой как огромный казан (тос-таңма - букв.: девять печатей) пиалой черпал [и] когда Аржы ламы жена смотрела [на него], раз черпал, в два-три глотка пил, когда отворачивалась, одну [полную хойтпаком] пиалу в один глоток (залпом) выпивал. Жена [Аржы ламы] один раз [как] глянула, мальчик көгээра [содержимое всё выпил] остатки наливал [в пиалу] и пил - вот так былоз

Далън күүн дамжилдъг/ Далһа шаръ шаазъңгар / Дараһар далън нэгэ / Дарад ууһад орквъ (Джангар, 1978а: 46) / Выпил [арзы] подряд / Семьдесят один раз / Из большой чаши / Которую поднимают семьдесят человек.

Идентичность семантики приведенных формул проявляется в указании гигантских размеров сосудов для напитка и большого количества глотков, сделанных богатырем из него. Исполинские черты и богатырские способности героя угадываются в противопоставлении его семидесяти человекам (далн күн) в калмыцкой версии, в тувинском сказании - многочисленному войску: (Кандыг кончуг улуг кырынныг кижи сен, Каңмы-Какпа хаанның ұш кавт шерии тоткаш, чоруй баар көгээр чүве - деп барып-

${ }^{1}$ Стр. 7 рукописи М. Б. Кунгаа.

${ }^{2}$ Стр. 10 рукописи М. Б. Кунгаа.

${ }^{3}$ Стр. 19 рукописи М. Б. Кунгаа.

${ }^{4}$ Стр. 21 рукописи М. Б. Кунгаа. 
тыр / С каким большим желудком ты, ненасытный, Каңмы-Какпа кагана многочисленное (үш каът букв.: в три слоя) войско насытившись, уезжает - такой вот этот көгээр - сказала) ${ }^{4}$.

В тувинском сказании «Богда Чангар хан» не получил должного развития мотив снаряжения юного героя. Оно состоит из черного лука со стрелами, переметной сумы и подзорной трубы.

Встреча в пути - распространенный элемент эпического повествования реализован в рассматриваемом сказании в той степени, чтобы показать факт пребывания героя в ином мире: герой общается с демоническими существами на протяжении шести лет.

\section{Гранииа.}

Фиксация границы играет важную роль в развитии эпического сюжета. Сказитель выбирает разные способы его обозначения, но для эпоса тюрко-монгольских народов характерным маркером границы является гора, встречающаяся богатырю на середине пути. Остановка на вершине горы дает возможность богатырю оценить свои возможности, обозрев масштабы чужого пространства:

Чер ортузу чорааш, тос кырлыг кызыл тайганың кырынга үне халдып кээп-тир. Чолдак кара дуранын ушта тырткаш, соңгу чүктү дураннап көрүп-түр.

На середине пути на вершину девятигранной Кызыл-Тайги (Кызыл - букв.: красный; тайга тайга) поднялся. Свою короткую черную подзорную трубу вытащив, северную сторону осматривал ${ }^{1}$.

Особое внимание уделяется дворцу враждебного хана, так как проникновение в него и уничтожение главного врага является целью визита эпического богатыря:

Ол дураннап көрүп турарга, Каңмы-Какпаның кода-хүрээзи үстүү дээрге үстүү ужу шаштыккан, алдыы ужу оран-делегей кыдыынга шаштыккан турар бооп-тур.

Когда в трубу осматривал [и увидел], Каңмы-Какпа дворец до верхних небес верхним краем упирался, нижний край земли края-конца упирался - вот так былоㅇ․

Формула, передающая величие и труднодоступность ханского дворца - оплота страны в тувинском сказании «Богда Чангар хан» выстроена в традиционной и для ойратской и калмыцкой версий эпоса «Джангар»:

Өл Маңхън Цаһан уулын .. ора дээрни һарчи ирәд / <.. > Киитен харъ нүдәрен тэлен / Дөрвен талан харвъ / Нарън суухин аръ өнцегте бәрүлсн/ һаслңта Шиле һәрде бәәшен үзегдве / Мана богдъ Жаңһриин бәәшеңде дорхъни/ Йамаран гилте? - гиһдд хархъла/ Өргндән аршъм өргън / Өндертән теңгеррте күрме болжи мэдегдеве (Джангар, 1978b: 16). Поднялся на вершину горы Ёл Манхан Цаган / Холодным пристальным взором / Окинул все стороны света/Увидел построенный на северо-западной стороне хрустальный скорбный дворец / <...> Посмотрев, подумал: каков он по сравнению с дворцом богдо Джангара? / Оказалось, что шире на целый аршин / А высотой почти достигает небес.

Объединяющим признаком в описании дворцов в сравниваемых нарративах является обозначение высоты, достигающей небес. Вертикаль, уходящая в высь или достигающая небес (мировая гора, одинокое дерево, золотая коновязь, ханский дворец), символизирующая ось в традиционной модели мира, обеспечивающая прочность и постоянство мира в сказании «Богда Чангар хан» и в эпосе «Джангар», указывает на общие истоки фольклорно-мифологических традиций тюрко-монгольских народов.

\section{Богатырское сражение.}

Олицетворением героизма в повествованиях эпического плана является богатырский поединок (борьба двух противников) или сражение (столкновение враждующих войск, борьба героя с многочисленными противниками). Эти баталии в эпосе рассматриваются как способ реализации богатырских амбиций, возможность продемонстрировать воинскую отвагу, физическую мощь, показать искусство владения оружием, борцовскими приемами и т. д. Безусловно, мотивацией для столь ответственного противостояния является защита отечества и подавление опасного врага. Описание этого действа составляет ключевое звено эпического повествования, оно отражает исключительные способности богатыря и вселенский масштаб происходящего: во время сражения содрогается земля, вздымается море-океан, река выходит из берегов, рушатся скалы, меркнет свет и т. д. Детализация изображения богатырских баталий в эпосе монгольских народов достигает своей кульминации при констатации исхода длительного и изнурительного противостояния. Коллизия богатырей-антагонистов включает несколько звеньев: узнавание соперника, поединок (сражение), помощь, поражение

${ }^{1}$ Стр. 13 рукописи М. Б. Кунгаа.

${ }^{2}$ Стр. 15 рукописи М. Б. Кунгаа. 
противника, сожаление поверженного богатыря, победа). Описание каждого из них дает несколько уровней минимальных константных единиц. К примеру, в калмыцкой версии «Джангара» описание поединка включает такие константные сегменты: взаимные дерзкие выпады богатырей; схватка с применением оружий (меча, секиры, кинжала, плетки, пики, копья, стрелы), магических предметов, с обращением к небесным силам, духам-покровителям; нанесение ударов в голову, в лопатку, в горло, по позвонку, по ребрам, в пах, по конечностям противника; единоборство силой, унаследованной «от отца и матери» (уходят в землю по пояс, по колено, по локоть); пограничное состояние между жизнью и смертью; борьба с боевым кличем «Ура!»; проникновение во дворец хана-антагониста с преодолением несколько рядов крепостей, бесовок, огнедышащего верблюда-самца, внешней стражи, внутренней охраны, зловещих хищников; продолжительность поединка (измеряется сутками - 4, 7, 12, 21, 49; месяцами - 3, 7, 8; безвременьем «не зная, ночь или день», «не зная, сколько времени прошло» и т. д.); численность противников (60000, 80000, 100000 и т. д.) (Хабунова, 2006: 139-142).

Несмотря на лаконичность текстовой реализации мотива борьбы героя с противниками в тувинском сказании «Богда Чангар хан», в нем присутствует ряд элементов, важных для сюжетосложения эпического нарратива: преодоление препятствий, уничтожение стражи, противостояние войску нескольких слоев, смертельное ранение, уход от преследования многочисленного вражеского войска:

Оол тура халааш, «Хөй шеригге сөс чедирер болар» дээш, селемези-биле баштарын одура шаап, өлүрүп кааптып-тыр. Оон оол кежээ каккаш, беттинде каът шеригге барып-тыр. Шериг-даа хая-даш турган, хараган-ыяш сөккен, «Каңзмы-Какпа хаан удуй берген, оон тургаш, Богда Чаңгар хаан-биле чаалажып чоруур» деп турар бооп-тур. Ол дүне оол ортаа кавт шеригге кирип-тир.Оран-делегейниң ыяжын бөлуп, хая-дажын туруп, «Каңммы-Какпа хаан удуп чыдыр, оон тургаш, Богда Чаңгар хаан-биле дайынче чоруур» дижип турар болган. Ол шериг: «Бистиң Какпа хаан удуп чыдырда, ийи кара маадыр өгде кадарган, ийи эгер, казар ыттар даштын кадарган турар чүве ийик» дижип турлар. Каңмыь-Какпа кадайы-биле удуп чыдырда, ийи бажын үзе шапкылааш, үнгеш, аъттангаш, ам алгырарда, ийи кара мөге тура халчып, ийи бүүректи көргеш... Абттангаштың, үш кабт шеригни ажа халыткаш, хүн-даа үнмес, даң-даа атпас кылгаш, хап чаныптып-тыр.

Мальчик вскочив, «Многочисленному войску донос (сөс - букв.: слово) донесут они (болар букв.: эти)» сказав, своим мечом их головы отрубив, убил. После мальчик, вечером поехав, первый (беттинде - букв.: спереди) слой войска достиг. Войско скалы-камни вырывал, караганникидеревья вырывал, «Каңмы-Какпа каган спит, после вставши, с Богда Чаңгар каганом воевать поедет» говорили - вот так было. В ту ночь мальчик в средний слой войска вошёл. Вселенной деревья собирали, скалы-камни вырывали, «Каңмы-Какпа каган спит, после вставши, с Богда Чаңгар каганом войну отправится» говорили - вот так было. То войско: «Когда наш Какпа каган спит, два лихих (кара - букв.: черный) в юрте сторожат, два злых эгер, казар снаружи сторожат, как правило» говорило. Когда Каңмы-Какпа и его жена спали, обоих головы отрубив, выйдя, на коня сев, как закричал. [Чиргилчинниг-Шил-оол] поехав, три слоя войска переехав, [чтоб] солнце не всходило, рассвет не наступал, сделав, поехал домой ${ }^{1}$.

В сочетании слов «эгер казар» угадываются активные персонажи сказочно-эпических повествований ойратов и калмыков - собаки Хаср Баср.

\section{Погоня и смертельное ранение.}

Обратный путь героя также полон опасностей, он уходит от преследования благодаря своему богатырскому коню. Эпизод, изображающий как вражеская стрела - оружие дальнего боя - настигает героя на подступах к рубежной горе, является типичным для монголо-ойратского, синьцзян-ойратского и калмыцкого эпоса:

Оон көрүп турарга, Шил-оол тос кырлыг кызыл тайганың кырында үне берген бар чыдып-тыр. Бистиң Каңмы соп каан огу эки-ле ийин - дээш, ийи маадыр адарга, Шил-оолдуң артындан киргеш, мурнундан үндүр өттүр адыптып-тырлар.

Когда оттуда осматривали [то увидели, что], Шил-оол девятигранной Кызыл-Тайги вершины достигнув, удалялся. Нашим Каңмы [каганом] кованая стрела хороша! - сказав, когда два богатыря выстрелили, Шил-оола спину воткнув, из груди (мурнундан - букв.: спереди) насквозь выстрелили².

${ }^{1}$ Стр. $24-33$ рукописи М. Б. Кунгаа.
${ }^{2}$ Стр. 37 рукописи М. Б. Кунгаа. 
Исключительные способности юного богатыря в тувинском сказании проявляются не только в его отважном противостоянии многослойному вражескому войску и грозной страже, но и в его умении управлять природной стихией. Идеализации образа Чиргилчинниг-Шил-оола способствуют качества, указывающие на его находчивость, решительность, ловкость, смекалку. Как и в эпосе монгольских народов, герой тувинского сказания способен ожить после смертельного ранения, а роль целительницы отводится небесной деве (тувин.: «даңгына», ойрат.- монг.: «дагина», калм.: «арагни»).

\section{Заключение}

Тувинское сказание «Богда Чаңгар хаан» (Богда Чангар хан) является результатом творчества тувинского сказителя Баяна Балбыра Узуновича, знакомого с ойратской эпической традицией и сумевшего адаптировать «принесенный» сюжет в тувинскую фольклорную среду, сохранив важные для эпического повествования константные сегменты (весть об угрозе войны, выбор богатыря, обретение богатырского коня, отправление в дорогу, граница, борьба с противниками, чудесное исцеление и т. д.) и, указывающие на типологическое сходство эпической традиции тюрко-монгольских народов.

Заимствование оказалось настолько успешным, что конструктивные элементы ойратского (калмыцкого) эпоса, не утратили свою героическую семантику, но при этом обрели новое звучание, наполнились этническими чертами тувинского фольклора.

Поэтико-стилевое сходство тувинского сказания «Богда Чангар хан» и эпоса ойратов и калмыков «Джангар» легко угадывается благодаря «опорным» словам, скрепляющим в «пучок» формульные словосочетания, отражающие стереотипы художественного мышления тувинцев и соседствующих с ними западно-монгольских ойратов, сородичей российских калмыков.

Микроконстанты, вербализованные в рассматриваемых произведениях на уровне «опорных» слов помогают понять глубинный смысл идей, выпяченных сказителем, обнаружить ключевые моменты эпического повествования, а через них - общие истоки фольклорно-мифологических традиций тюрков и монголов.

\section{СПИСОК ЛИТЕРАТУРЫ}

Аман зохиол судлал [Исследование фольклора] (1978) / сост. и автор предисл. У. Загдсурэн. Улаанбатаар : Шинжлэх Ухааны Академийн хэвлэл. 234 с. (На монг. яз.).

Гацак, В. М. (2000а) Северные этнопоэтические константы [Электронный ресурс] // Северный (Арктический) Федеральный университет. URL: https://narfu.ru/upload/iblock/988/gatsak-v.m.-severnyeetnopoeticheskie-konstanty-.pdf (дата обращения: 05.07.2019).

Гацак, В.М.(2000b) Фольклор - память традиции:уровни и формы этнопоэтической константности // Вестник ДНЦ РАН. № 8. С. 94-103.

Гацак, В. М. (2002) Этнопоэтические константы в фольклоре: уровни, изоглоссы, «мультимедийные формы» (на славянском и неславянском материале) // Литература, культура и фольклор славянских народов: XIII Междунар. съезд славистов (Любляна, август 2003 г.): Докл. росс. делегации / ред. Л. И. Сазонова. М. : Институт мировой литературы им. А. М. Горького (ИМЛИ). 435 с. С. 313-314.

Гребнев, Л. В. (1960) Тувинский героический эпос (опыт историко-этнографического анализа). М. : Издательская фирма «Восточная литература». 145 с.

Джангар. Калмыцкий героический эпос (1978a). Тексты 25 песен : в 2-х т. / сост. А. Ш. Кичиков. М. : Главная редакция восточной литературы издательства «Наука». Т. 1. 441 с.

Джангар. Калмыцкий героический эпос (1978b). Тексты 25 песен : в 2-х т. / сост. А. Ш. Кичиков. М. : Главная редакция восточной литературы издательства «Наука». Т. 2. 411 с.

Жирмунский, В. М. (1974) Тюркский героический эпос. Л. : Наука. 720 с.

Загдсурэн, У. (1978) Удиртгал [Предисловие] // Аман зохиол судлал. [Исследование фольклора]. Улаанбатаар : Шинжлэх Ухааны Академийн хэвлэл. 234 с. С. 3-58.

Кичиков, А. Ш. (1973) О тувинской богатырской сказке «Богда Чаңгар-хаан» // Учёные записки. Выпуск XI (серия филологии). Элиста : КНИИЯЛИ. 238 с. С. 118-121. 
Короглы, Х. Г. (1975) Огузский эпос (Сравнительный анализ) // Типология народного эпоса / отв. ред. В. М. Гацак. М.: Наука. 326 с. С. $64-81$.

Кунгаa, М. Б. (2019) Тувинские фольклорные сюжеты, восходящие к «Джангару» // “Дэлхийн тууль ба «Жангар»” [Эпосы мира и «Джангар»]. Олон улсын симпозиум. Туулийн наадам. 2018 оны 9 сарын 21-23. Ред. Б. Катуу, Г. Батмөнх. Улаанбаатар : Соёмбо принтинг ХХК. 312 с. С. 120 -123.

Куулар, Д. С. (1973) Богда Чаңгар хан (Тувинский эпос) // Учёные записки. Выпуск XI (серия филологии). Элиста : КНИИЯЛИ. 238 с. С. 122-129.

Куулар, Д. С. (2004) Тувинская версия «Джангара» // «Джангар» и проблемы эпического творчества». Материалы международной научной конференции 22-24 августа 1990 года / отв. ред.: Н. Ц. Биткеев, Э. Б. Овалов. Элиста : АПП «Джангар». 601 с. С. 143-148.

Лорд, А. Б. (1994) Сказитель / пер. с англ. и комм. Ю. А. Клейнера и Г. А. Левинтона. М. : Издательская фирма «Восточная литература». 368 с.

Мелетинский, Е. М. (1963) Происхождение героического эпоса. М. : Издательская фирма «Восточная литература». 459 с.

Орус-оол, С. М. (2001) Тувинские героические сказания (текстология, поэтика, стиль). М. : МАКС Пресс. 422 с.

Путилов, Б. Н. (1997) Эпическое сказительство: Типология и этническая специфика. М. : Издательская фирма «Восточная литература». 295 с.

Пухов, И. В. (1975) Героический эпос тюрко-монгольских народов Сибири: общность, сходство, различия // Типология народного эпоса / отв. ред. В. М. Гацак. М. : Наука. 326 с. С. 12-63.

Суразаков, С. С. (1985) Алтайский героический эпос. М. : Наука. 256 с.

Убушиева, Д. В., Дамринжав, Б. (2019) Матримониальные коллизии в калмыцком эпосе «Джангар» и сказаниях тюрко-монгольских народов Сибири // Oriental Studies. № 44 (4). C. 707-715. DOI: 10.22162/2619-0990-2019-44-4-707-715

Хабунова, Е. Э. (2006) Героический эпос «Джангар»: поэтические константы богатырского жизненного цикла (сравнительное изучение национальных версий). Ростов н/Д: Изд-во СКНЦ ВШ. 256 с.

Reichl, K. (1992) Turkic Oral Epic Poetry: Traditions, Forms, Poetic Structure. New York \& London: Garland Publishing, Inc. 395 p.

Дата поступления: 28.08.2019 2.

\section{REFERENCES}

Aman zokhiol sudlal [Investigating folklore] (1978). Comp. by Y. Zagdsuren. Ulaanbataar, Mong. Acad. of Sc. 234 p. (In Mong.)

Gatsak, V. M. (2000a) Severnye etnopoeticheskie konstanty [Northern ethno-poetic constants]. Severnyi (Arkticheskii) Federal'nyi universitet [online] Available at: https://narfu.ru/upload/iblock/988/gatsak-v.m.severnye-etnopoeticheskie-konstanty-.pdf (access date: 05.07.2019). (In Russ.).

Gatsak, V. M. (2000b) Fol'klor - pamiat' traditsii: urovni i formy etnopoeticheskoi konstantnosti [Folklore the memory of tradition: levels and forms of ethno-poetic constancy]. Vestnik DNTs RAN, no. 8, pp. 94-103. (In Russ.).

Gatsak, V. M. (2002) Etnopoeticheskie konstanty v fol'klore: urovni, izoglossy, «mul'timediinye formy» (na slavianskom i neslavianskom materiale) [Ethnopoietic constants in folklore: levels, isoglosses, 'multimedia forms' (a case study of Slavic and non-Slavic language materials)]. In: Literatura, kul'tura i fol'klor slavianskikh narodov [Literature, culture and folklore of Slavic peoples]. $13^{\text {th }}$ International Congress of Slavists (Ljubljana, August 2003), reports of Russian scientists / ed. by L. I. Sazonova. Moscow, Gorky Institute of World Literature (IMLI). 435 p. Pp. 313-314. (In Russ.).

Grebnev, L. V. (1960) Tuvinskii geroicheskii epos (opyt istoriko-etnograficheskogo analiza) [Tuvan heroic epos (experience of historical and ethnographic analysis)]. Moscow, Vost. Lit. 145 p. (In Russ.).

Dzhangar. Kalmytskii geroicheskii epos [Jangar. The Kalmyk heroic epic] (1978a). Texts of 25 songs in 2 vols. Comp. by A. Sh. Kichikov. Moscow, Nauka, GRVL. Vol. 1. 441 p. (In Russ.). 
Dzhangar. Kalmytskii geroicheskii epos [The Jangar. Kalmyk heroic epic] (1978b). Texts of 25 songs in 2 vols. Comp. by A. Sh. Kichikov. Moscow, Nauka, GRVL. Vol. 2. 411 p. (In Russ.).

Zhirmunsky, V. M. (1974) Tyurkskii geroicheskii epos [Turkic heroic epic]. Leningrad, Nauka. 720 p. (In Russ.). Zagdsuren, U. (1978) Preface. In: Aman zokhiol sudlal [Investigating folklore]. Ulaanbaatar, Mong. Acad. of Sc. 234 p. Pp. 3-58. (In Mong.).

Kichikov, A. Sh. (1973) O tuvinskoi bogatyrskoi skazke «Bogda Changgar-khaan» [About the Tuvan heroic tale ‘Bogda Chagar-Khan']. Uchenye zapiski. Vol. XI. Elista, KNIIYaLI. 238 p. Pp. 118-121. (In Russ.).

Korogly, Kh. G. (1975) Oguzskii epos (Sravnitel'nyi analiz) [Oguz epic: (Comparative analysis)]. In: Tipologiia narodnogo eposa [Typology of the folk epic]. Ed. by V. M. Gatsak. Moscow, Nauka. 326 p. Pp. 64-81. (In Russ.).

Kungaa, M. B. (2019) Tuvinskie fol'klornye siuzhety, voskhodiashchie k «Dzhangaru» [Tuvan folklore stories tracing their origin to the Jangar]. In: "Delkhiin tuul' ba «Zhangar»" [Epics of the world and the Jangar]. International symposium. 2018. Ed. by B. Katuu and G. Batmönkh. Ulaanbaatar, Soembo Printing. 312 p. Pp. 120 -123. (In Russ.).

Kuular, D. S. (1973) Bogda Changgar khan (Tuvinskii epos) [Bogda Changgar khan (a Tuvan epic)]. In: Uchenye zapiski. Vol. XI. Elista, KNIIYaLI. 238 p. Pp. 122-129. (In Russ.).

Kuular, D. S. (2004) Tuvinskaia versiia «Dzhangara» [A Tuvan version of the Jangar]. In: Dzhangar» i problemy epicheskogo tvorchestva [The Jangar and problems of epic creativity]. Proceedings of the International scientific conference, 22-24 August 1990 / ed. by N. Ts. Bitkeev and E. B. Ovalov. Elista, Dzhangar. 601 p. Pp. 143-148. (In Russ.).

Lord, A. B. (1994) Skazitel' [The Taleteller]. Transl. from Engl. and comm. by Yu. A. Kleiner and G. A. Levinton. Moscow, Vost. Lit. 368 p. (In Russ.).

Meletinsky, E. M. (1963) Proiskhozhdenie geroicheskogo eposa [Origins of the heroic epic]. Moscow, Vost. Lit. 459 p. (In Russ.).

Orus-ool, S. M. (2001) Tuvinskie geroicheskie skazaniia (tekstologiia, poetika, stil') [Tuvan heroic legends (textology, poetics, style)]. Moscow, MAKS Press. 422 p. (In Russ.).

Putilov, B. N. (1997) Epicheskoe skazitel'stvo: Tipologiia i etnicheskaia spetsifika [Epic narration: typology and ethnic specificity]. Moscow, Vost. Lit. 295 p. (In Russ.).

Pukhov, I.V.(1975) Geroicheskii epos tiurko-mongol'skikh narodov Sibiri: obshchnost', skhodstvo, razlichiia [Heroic epic of Siberian Turko-Mongols: commonness, similarities, differences]. In: Tipologiia narodnogo eposa [Typology of the folk epic]. Ed. by V. M. Gatsak. Moscow, Nauka. 326 p. Pp. 12-63. (In Russ.).

Surazakov, S. S. (1985) Altaiskii geroicheskii epos [The Altaian heroic epic]. Moscow, Nauka. 256 p. (In Russ.).

Ubushieva, D. V. and Damrinzhav, B. (2019) Matrimonial'nye kollizii v kalmyckom epose «Dzhangar» i skazaniyah tyurko-mongol'skih narodov Sibiri [Matrimonial Collisions in the Kalmyk Epic of Jangar and Legends of Siberia's Turko-Mongols]. Oriental Studies, no. 44(4), pp. 707-715. DOI: 10.22162/2619-09902019-44-4-707-715 (In Russ.).

Khabunova, E. E. (2006) Geroicheskii epos «Dzhangar»: poeticheskie konstanty bogatyrskogo zhiznennogo tsikla (sravnitel'noe izuchenie natsional'nykh versii) [The heroic epic of Jangar: poetic constants of the heroic life cycle (a comparative study of national versions)]. Rostov-on-Don, North Caucasus Scientif. Center. 256 p. (In Russ.).

Reichl, K. (1992) Turkic Oral Epic Poetry: Traditions, Forms, Poetic Structure. New York \& London, Garland Publishing, Inc. 395 p. 